\title{
Post-Colonialism Context inside Wigatining Wulangan Sujarah (Geguritan by Bambang Nursinggih)
}

\author{
Erwin Indrayana ${ }^{1}$, Sarwiji Suwandi ${ }^{2}$, Suyitno $^{3}$, and Kundharu Saddhono ${ }^{4}$ \\ \{erwindrayana@gmail.com¹, sarwijiswan@yahoo.com², yitsuyitno52@gmail.com ${ }^{3}$, \\ kundharu_s@staff.uns.ac.id ${ }^{4}$ \} \\ ${ }^{1,2,3}$ Universitas Sebelas Maret, Surakarta, Indonesia
}

\begin{abstract}
Geguritan is one of literary work who formed as poetry. This research aims to knowing historical values that inside Geguritan Wigatining Wulangan Sujarah by Bambang Nursinggih. The research method is qualitative descriptive. Geguritan Wigatining Wulangan Sujarah invite the students to learn history so could become wiser. The research result shows historical events and figures Sumpah Palapa, Gadjah Mada, Pancasila, Indonesian Proclamator Sukarno-Hatta, $7^{\text {th }}$ October 1756 as Jogjakarta city anniversary.
\end{abstract}

Keywords: Post-Colonialism, Geguritan, Poetry

\section{INTRODUCTION}

The emergence of the idea of postcolonial literary theory according to Aschroft, dkk [1] is derived from the inability of European literary theory to explain the complexity and diversity of cultural resources that exist in postcolonial works appropriately. This means that postcolonial is used widely and in various ways, including the study and analysis of indigenous peoples' resistance in facing colonialism before and after independence.

Next, postcolonial depends on Ratna [2] opinion that postcolonially definitively paid attention to analyzing the colonial era. Ratna considers that postcolonialism is very compatible with the problems faced by Indonesia. So, there are still many problems that must be solved in relation to the history of the Indonesian nation. Postcolonialism is closely related to history so that it does not rule out the possibility that postcolonial analysis is no different from social history, history of movement, and various issues related to nationalism. Postcolonialism is closely related to nationalism, because postcolonialism theory can provide an understanding of each individual in order to always prioritize the interests of the group above personal interests.

Geguritan is a form of literature besides prose and drama. In fact, geguritan in Javanese literature is a type of literature in the form of poetic art [3]. Furthermore, Waluyo and Sutarjo said modern Javanese poetry no longer using rules about stanza (guru gatra), alignment (guru wilangan), rhytmes (guru lagu) like inside tembang [3].

Geguritan as a form of resistance encourages the power of aspiration, and establishes the awareness of society. Salad [4] categorizes this as poem/ pamphlet geguritan, or equal to poem/social geguritan. This kind of geguritan contains of dominant elements about the critique towards social-politic reality which had occured or is occuring in the local society, whether in the national or international level. 
Subalidinata [5] stated that geguritan yaiku iketaning basa kang memper syair, mula ana sing ngarani syair Jawa gagrag anyar. "Geguritan is language arrangement like poetry so someone stated new Javanese poetry style". Based on that understanding, can be interpreted that geguritan is language arrangement like poetry that belong to the new Javanese poetry group which contains the beautifully expression of poet feelings and refer to aesthetic experience.

What we want to find in here is, the historical points that has a connection with the postcolonialism theory. This research is expected to provide new treasures among existing studies such as Contemporary African Poetry: A Postcolonial Reading of Iquo Eke's Symphony of Becoming and Ifeanyi Nwaeboh's Stampede of Voiceless Ants [6], The Home and Identity: A Postcolonial Journey in the Poems of Meena Alexander [7], and Postcolonial Feminism In The Poems Of Kamala Das [8].

\section{METHOD}

The method used in this study is qualitative descriptive research method by taking subject of literature. Data source of this research is geguritan Wigatining Wulangan Sujarah by Bambang Nursinggih contained in the Arak-Arakan Geguritan: Jogja Sinangling Gurit book.

\section{RESULT AND DISCUSSION}

Geguritan Wigatining Wulangan Sujarah:

Ujare para winasis, siswa kudu gelem sinau sujarah Murih bisa dunung asal-usul lan ngajeni pahlawan kang bebadra negara

Jalaran wulangan sujarah ing pawiyatan :

Siswa dhamang, Sumpah Palapa

sujarah prasetyane patih Gadjah Mada

kang nedya manunggalake Nuswantara

ing jaman kamardikan kawahya njilma Pancasila

minangka dhasaring negara Republik Indonesia

kang kakepyakake dening Bung Karno

Siswa weruh, Sumpah Pemuda sujarahe basa Indonesia

minangka basa persatuan

Siswa wanuh, kamardikane bangsa Indonesia

uwal saka panjajah Jepang lan Walanda

Siswa kurmat marang Proklamator Indonesia Sukarno-Hatta

Siswa dunung Istimewane Dhaerah Istimewa Yogyakarta

Siswa uga dhong lamun tanggal 7 Oktober 1756

kang titi wanci iki katelah hari jadi kota Jogjakarta

Iku wigatine wulangan sujarah tumrap pawiyatan

Lamun siswa bisa dadi pejabat datan nyelaki sujarah

kepara kurmat marang kang ngukir endah sujarahe bangsa

Kang tundhone lembah manah, agung tepa slirane

bawa laksana datan cidra ing ubaya

Negara raharja rakyat mulya tanpa kasikara bangsa manca 


\section{Translation}

Told by smart person, student should be want to learn about history

Desired could know the origin and respect the heroes

who be the country pioneer

Because of the historical teachings in school: Student really know, Sumpah Palapa

the history of the loyalty patih Gadjah Mada

who will unite Nuswantara

in independence age born incarnate Pancasila

as the basic of Indonesian Republic country

who announced by Bung Karno

Student know, Sumpah Pemuda the Indonesian language history

that be the unity language

Student already know, the independence of Indonesian country

separate from the invaders Japan and Holland

Student respect to Indonesian Proclamator Sukarno-Hatta

Student know how special is Dhaerah Istimewa Yogyakarta

Student also know if 7th October 1756

is the time called Jogjakarta anniversary

That was important for history lesson in school

If student could be the officials won't deny the history

better respect to who carve the magnificent of the nation history

Who repeatedly lembah manah, big in tepa slira

bawa laksana not deny the promise

Prosperous country noble people without the disturbance from overseas nation

By examining Geguritan Wigatining Wulangan Sujarah using postcolonial theory, we get five important points presented by the author:

\subsection{Sumpah Palapa}

Realization of the Sumpah Palapa, Gadjah Mada achieve success during Hayam Wuruk's reign. This can be proven that Majapahit at those time could dominate Nusantara areas which cover Melayu (Sumatra), Tanjungpura (Kalimantan), Semenanjung Melayu (Malaka), east side of Java and Nusa Tenggara, Sulawesi, Maluku, Irian Barat, and Java (except Sunda Galuh kingdom and Sunda Pakuan). Thanks to this success, Gadjah Mada effect in Majapahit getting bigger. Even the effect can be said go beyond Hayam Wuruk and Saptaprabhu member (sort of Dewan Pertimbangan Agung which has a number of characters Majapahit Kingdom family). [9]

The author of this Geguritan want to show and proud that Indonesia is really wide like Nusantara that said in Sumpah Palapa.

\subsection{Gadjah Mada}

At that time, precisely in the $14^{\text {th }}$ century, was born a national figure from the common people, from castes which are not taken into account. Armed with the philosophy of unity of Nusantara contained in serat Pararaton, Sumpah Amukti Palapa, spoken in Paseban Agung Majapahit in 1334, Gadjah Mada is a political figure at that time has provided enormous 
inspiration for the formation of a Indonesian Republic unitary state. The success of uniting this heterogeneous nation has enriched the nation's culture to be a great and authoritative nation in the eyes of neighboring countries. The philosophy of persatuan dan kesatuan that was proclaimed was proven has brought this nation to the golden age. [10]

\subsection{Pancasila}

Pancasila has motto Bhinneka Tunggal Ika, with the pluralism and multiculturalism that should be unite with "togetherness"inside idiom nationstate following the spirit of nationalism that accompanied it. Of course it can have a big influence in creating a union with the same goal, which is to uphold the values of divinity, humanity, unity and civilization. The motto cannot be separated from the Indonesian people who have different backgrounds, as written by Empu Tantular: "Bhinneka Tunggal Ika Tan Hana Darma Mangrwa". It shows that Pancasila is a tool of unity of diversity that exists in the country of Indonesia, multicultural and also pluralistic Indonesian people. [11]

\subsection{Proclamator}

Soekarno who was born in Surabaya in $6^{\text {th }}$ June 1901 and Moh Hatta who was born in Bukittinggi $12^{\text {th }}$ August 1902, have different characters. Educational conditions also effect character, attitude and direction of the battle strategy. Soekarno who got education in domestic tend to be radical against any colonial pressure. During the journey formed the spirit of nationalism and organizational leadership. Soekarno followed the Tri Koro Darmo youth movement. Hatta developed his leadership by following Jong Sumatranen Bond (JSB). We see deeper Soekarno's background who is a Javanese, while Hatta is a Minang person, seen from their personality it is very clear that there will be great potential for conflict. [12]

On July 9, 1942, Soekarno, who had been sent to Jakarta by the Japanese, meet with Hatta and Sjahrir. Those three held a meeting at Hatta's house and agreed that Soekarno Hatta was working with Japan, and Sjahrir with the Student Association in Jakarta compiled an underground resistance. [13] Likewise with Soekarno, his willingness to cooperate with the Japanese was based on the same principles as Hatta. [14]

Soekarno and Hatta proved that even though they had different characters, they remained united for the sake of Indonesian independence.

\subsection{Jogjakarta Anniversary}

In 1755 Kraton Jogjakarta Hadiningrat was built in Pacethokan Village in Beringan Forest region. Precisely located in between Code River and Winonggo River. Meanwhile Sultan with their family live in Pesanggrahan Ambarketawang. [15] In $7^{\text {th }}$ October 1756, Sri Sultan HB I start to live in Kraton Jogjakarta, which has been marked with Dwi Naga Rasa Tunggal sengkalan, which shows 1682 Javanese year and which expresses the implicit meaning: SariRasa-Tunggal (The Nature of Unity) and Sarirasatunggal (Personality). Then on those $7^{\text {th }}$ October commemorated as Jogjakarta anniversary. The author shows his pride of Jogjakarta city by putting the Jogjakarta anniversary in his Geguritan [16].

\section{CONCLUSION}

Geguritan Wigatining Wulangan Sujarah invite the students to not forgetting historical events and actors, so could become a wiser personality. From those historical events and actors, we can appreciate the hard work and doing the positive things to fill the current independence period. Also could reach achievement in the respective fields and make this nation proud. 


\section{REFERENCES}

[1]. B. Ashcroft, dkk. Menelanjangi Kuasa Bahasa. Teori dan Praktik Sastra Poskolonial. (terjemahan: Fati Suwandi dan Agus Mokamat). Yogyakarta: Qalampress, 2003.

[2]. I. N. K. Ratna: Postkolonialisme Indonesia Relevansi Sastra. Yogyakarta: Pustaka Pelajar, 2008.

[3]. H. J. Waluyo \& I. Sutardjo. Bahasa dan Sastra Daerah (Paramasastra Jawi). Surakarta: Panitia Sertifikasi Guru Rayon 13 FKIP UNS, 2009.

[4]. H. Salad. Panduan Wacana dan Apresiasi Seni Baca Puisi. Yogyakarta: Pustaka Pelajar, 2014.

[5]. Subalidinata. Kawruh Kasusastraan Jawa. Yogyakarta: Yayasan Pustaka Nusatama, 1994.

[6]. I. Okiche. Contemporary African Poetry: A Postcolonial Reading of Iquo Eke's Symphony of Becoming and Ifeanyi Nwaeboh's Stampede of Voiceless Ants. Akpabuyo: Arthur Jarvis University, 2018.

[7]. S. Sarkar and A. Haque. The Home and Identity: A Postcolonial Journey in The Poems of Meena Alexander. USA: Center for Promoting Ideas, 2018.

[8]. V. Kavitha. Postcolonial Feminism in the Poems of Kamala Das. Chennai: Dr.M.G.R. Educational and Research Institute, 2018.

[9]. S. W. Achmad. 13 Raja Paling Berpengaruh Sepanjang Sejarah Kerajaan di Tanah Jawa. Yogyakarta: Araska, 2016.

[10]. R. Masmada. Gajah Mada Sang Pemersatu Bangsa. Jakarta: Elex Media Komputindo, 2003.

[11]. A. Irhandayaningsih. Peranan Pancasila Dalam Menumbuhkan Kesadaran Nasionalisme Generasi Muda Di Era Global. Humanika. Vol 16. Th. IX Juli- Desember 2012.

[12]. M. Rauf. Konsensus Politik. Jakarta. Halaman: 115-117, 2000

[13]. M.C. Ricklefs: Sejarah Indonesia Modern 1200-2008. Jakarta: Serambi, 2009.

[14]. M. Djoened and N. Notosusanto. Sejarah Nasional Indonesia VI. Jakarta: Balai Pustaka, 1984.

[15]. K. Sabdacarakatama. Sejarah Kraton Yogyakarta. Yogyakarta: Narasi, 2009.

[16]. K. Saddhono, "Cultural and social change of foreign students in Indonesia: The influence of Javanese Culture in Teaching Indonesian to Speakers of Other Languages (TISOL)." IOP Conf. Ser.: Ear. and Envi. Sci.. vol. 126 no. 1 IOP Publishing, 2018. 